\title{
Exercise induced anterolateral lower leg pathologies
}

Citation for published version (APA):

van Zantvoort, A. P. M. (2021). Exercise induced anterolateral lower leg pathologies: Chronic exertional compartment syndrome and nerve antrapment. [Doctoral Thesis, Maastricht University]. Maastricht University. https://doi.org/10.26481/dis.20210707az

Document status and date:

Published: 01/01/2021

DOI:

10.26481/dis.20210707az

Document Version:

Publisher's PDF, also known as Version of record

\section{Please check the document version of this publication:}

- A submitted manuscript is the version of the article upon submission and before peer-review. There can be important differences between the submitted version and the official published version of record.

People interested in the research are advised to contact the author for the final version of the publication, or visit the DOI to the publisher's website.

- The final author version and the galley proof are versions of the publication after peer review.

- The final published version features the final layout of the paper including the volume, issue and page numbers.

Link to publication

\footnotetext{
General rights rights.

- You may freely distribute the URL identifying the publication in the public portal. please follow below link for the End User Agreement:

www.umlib.nl/taverne-license

Take down policy

If you believe that this document breaches copyright please contact us at:

repository@maastrichtuniversity.nl

providing details and we will investigate your claim.
}

Copyright and moral rights for the publications made accessible in the public portal are retained by the authors and/or other copyright owners and it is a condition of accessing publications that users recognise and abide by the legal requirements associated with these

- Users may download and print one copy of any publication from the public portal for the purpose of private study or research.

- You may not further distribute the material or use it for any profit-making activity or commercial gain

If the publication is distributed under the terms of Article $25 \mathrm{fa}$ of the Dutch Copyright Act, indicated by the "Taverne" license above, 


\section{SUMMARY}

Anterolateral lower leg pain syndromes are common in active populations often limiting sports activities. In the present thesis, we studied several anterolateral lower leg pain syndromes with emphasis on the lateral chronic exertional compartment syndrome (CECS) and common peroneal nerve (CPN) pathologies.

Symptoms in CECS are believed to be caused by exercise-induced elevation of intracompartmental pressures (ICP) resulting in relative muscle ischemia, but details regarding the underlying pathophysiology are lacking. CECS can occur in any muscle compartment but is most frequently diagnosed in one of the 3 lower leg compartments; the anterior (ant-CECS), deep posterior (dp-CECS) or lateral compartment (lat-CECS). Numbers on prevalence of these 3 distinct compartment syndromes are contradictory, with the lateral compartment mostly referred to as the least affected. ${ }^{15,36,40,53,65}$ However, studies reporting a high lat-CECS prevalence consider the anterior and lateral compartment syndrome as one entity ('anterolateral-CECS'), although this diagnosis is made by an ICP of the anterior compartment only. ${ }^{53,65}$ Until today, consensus is not only lacking regarding prevalence but to almost all aspects of lat-CECS, ranging from unknown patient characteristics to type of optimal conservative and surgical treatment.

Current knowledge on characteristics of CECS patients is largely based on studies with selected cohorts of athletes or military service members. ${ }^{11,39,40,71}$ In chapter $\mathbf{2}$, we describe a large heterogenous civilian cohort of 1411 patients with exertional lower leg pain that was evaluated for possible lower leg CECS between January 2001 and December 2013 in our institution. Half of these patients was diagnosed with CECS in one or more compartments based on history and elevated ICP measurements. Median age was 25 years ranging from 12 up to 81 years. CECS prevalence decreased with advancing age. Using a multivariate regression model, young age, male gender, bilateral symptoms, clinical history without earlier lower leg pathology, a painful/tensed compartment on physical examination and skating were identified as positive predictors of CECS. Running was labelled as a negative predictor of CECS. These predictors were combined in a nomogram having a moderate discriminative ability (AUC 0.66). This predictive model may be used to support decision making in selecting patients who require invasive ICP measurements, but not as a diagnostic tool in itself.

If a physician suspects CECS of the lower leg, an ICP measurement is used to confirm or reject the diagnosis. ${ }^{47}$ However, the value of a repeated ICP measurement (re-ICP) in patients 
with recurrent or ongoing CECS-like symptoms after fasciotomy or an earlier normal ICP is unknown. In chapter 3 we aimed to examine the role of re-ICP in these two groups of patients. We retrospectively studied 1714 ICP measurement sessions in 1513 patients between January 2001 and December 2013. Seventy-one re-ICP measurements were found in 68 patients (after fasciotomy, $n=55$ measurements; previous normal ICP, $n=16$ ). Re-ICP was positive in $26 \%$ of all operated compartments, and in 15\% of all compartments where a previous ICP was normal. It may be concluded that, if other causes of lower leg exertional symptoms in patients with recurrent or residual symptoms are excluded, a re-ICP may be considered. However, false positive ICP measurement outcomes are not uncommon.

As mentioned earlier, there are three types of lower leg CECS: ant-CECS, dp-CECS and lat-CECS. The contribution of each subtype to a total CECS population is unknown and up for discussion. In general, ant-CECS and dp-CECS are considered 2 distinct syndromes that each can occur as an isolated form. ${ }^{5,75}$ The lateral compartment, however, is often seen as an entity that is only present in combination with ant-CECS. ${ }^{24,54}$ In chapter 4, we aimed to study whether lat-CECS can also present as an isolated entity. Moreover, we questioned whether specific clues in history taking and physical examination can be found that aid in discriminating between subtypes, in particular between ant-CECS and lat-CECS. This retrospective study included 73 of the total of 747 patients who underwent ICP measurements for possible CECS. Patients were included if they had a simultaneous ICP measurement of both the anterior and lateral compartment. Seven percent of this heterogenous CECS population with anterolateral pain and tightness was diagnosed with an isolated lat-CECS (isolated ant-CECS, $n=26$; isolated lat-CECS, $\mathrm{n}=5$; ant/lat-CECS, $\mathrm{n}=42$ ). There were no group differences regarding age (antCECS: median 26 years (range 13-68); lat-CECS: median, 20 years (range 17-63); ant/lat-CECS median 28 years (range 17-57); $\chi^{2}(2)=0.466 ; P=0.79$ ), sex (ant-CECS 50\% male, lat-CECS $40 \%$ male, ant/lat-CECS 62\% male; P =0.49), and bilaterality (ant-CECS 54\%; lat-CECS 80\%, ant/latCECS 69\%; P=0.40). All patients reported pain and all but one $(72 / 73,99 \%)$ reported some grade of tightness during exercise. Surprisingly, half had symptoms at night. Patient reported location of alterations in skin sensation did not correspond with areas that are innervated by the deep or superficial peroneal nerve in two thirds of the patients indicating that this type of information does not aid in the diagnosis. Since history and physical examination do not help in differentiating between ant-CECS and lat-CECS whereas both subtypes can occur as an isolated entity, dynamic ICP measurements of both compartments in patients reporting anterolateral symptoms are justified. 
CECS of the anterior and deep posterior compartment is discussed extensively in the

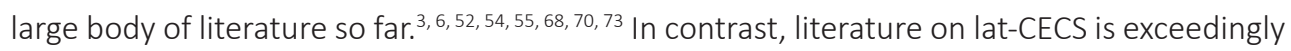
scarce. ${ }^{6,8,15,19,36,40,47,51,65}$ In chapter 5, we describe demographics and baseline characteristics in a retrospective series of patients diagnosed with isolated lat-CECS. Between January 2001 and December 2012, 1384 patients underwent an ICP for suspected CECS, and 678 were diagnosed with CECS according to the Pedowitz criteria. ${ }^{47}$ Twelve percent of all patients with a positive ICP were diagnosed with lat-CECS, either isolated or in combination with other types of CECS (lat-CECS: $n=28,4 \%$; ant/lat-CECS: $n=33,5 \%$; dp/lat-CECS: $n=7,1 \%$; ant/dp/lat-CECS: $n=10$, $1 \%)$. Twenty-six of the 28 patients with an isolated type lat-CECS were studied in detail. The small majority was female and median age at diagnosis was 27 years (range 16-78). Delay in diagnosis was a median 24 months (range 2 months - 10 years). Pain (24/26, 92\%) and a feeling of tightness (11/26, 42\%) were most frequently reported symptoms. Occasionally patients also reported cramps (19\%), diminished sensibility (15\%) and/or muscle weakness (12\%). These symptoms were reported bilaterally in two-thirds of patients $(16 / 24,67 \%$, unknown $n=2)$. In $87 \%$ of lat-CECS patients (13/26, $n=11$ unknown), CECS symptoms affected sports activities to a certain degree ( $27 \%$ completely abstained from sports activities, $47 \%$ continued at a lower level, $13 \%$ continued sports with substantial additional effort). This study concluded that a small portion of patients with CECS is having an isolated type of lat-CECS. However, lat-CECS may not be distinguished from other types of CECS as symptom patterns are much alike.

If CECS is diagnosed, a patient is informed about both conservative and surgical treatment options. Often, conservative therapies such as modification of gait pattern, physical therapy, icing or dry needling are first steps. If a CECS patient is not satisfied with the results of conservative therapy, fasciotomy is treatment of first choice. ${ }^{7,16,61,76}$ Currently, little is known about results of fasciotomy in lat-CECS. In chapter $\mathbf{6}$, we report on outcome of fasciotomy in a retrospective group of lat-CECS patients. A total of 247 patients underwent ICP measurements for suspected lat-CECS between January 2001 and December 2012, and 78 were diagnosed with lat-CECS. All patients were asked to complete a questionnaire scoring severity and frequency of symptoms at various time points and outcome of surgery. Success was defined as an excellent or good outcome as judged by the patient whereas a moderate, fair or poor result was termed unsuccessful. A total of 30 questionnaires of the eligible 67 patients allowed for analysis. Bilateral (80\%) exertional pain (97\%) and a feeling of tightness (93\%) were the most frequently reported symptoms. However, patients also often experienced exertional muscle weakness (73\%), paraesthesia's (70\%) and/or cramps (70\%). Four years after the fasciotomy, severity and 
frequency of all of these symptoms had dropped significantly, with a decrease in mean pain score $>50 \%$. Long-term surgical success was just 33\%. Seventy-three percent had resumed sports activities, albeit often at a lower level than before the start of CECS symptoms. It was concluded from this retrospective analysis that long term outcome of surgery for lat-CECS in general was beneficial although just one in three patients termed the outcome a success.

To optimally assess surgical outcome, we initiated a prospective study that is discussed in chapter 7. Between January 2013 and April 2019, 881 patients with exertional lower leg pain (ELP) were analysed for possible CECS in our institution, and 88 were diagnosed with lat-CECS (male, 57\%; mean age $27 \mathrm{yr}$, range 15-72 yr). Severity and frequency of cardinal symptoms (pain, tightness, cramps, muscle weakness and paresthesia) were scored on a 5-point verbal rating scale during exercise and at rest, before and 3 and 12 months after a fasciotomy. The majority of lat-CECS patients had a combination with other compartments including antCECS (61\%) or dp CECS (6\%). An isolated lat-CECS was present in just 11\%. The results in 47 operated patients (78 legs) indicated that severe pain during exercise (>90\%) and moderate tightness during rest (83\%) were frequently reported symptoms. A 10\% total complication rate was found ( 2 wound infections requiring antibiotic therapy, 2 hematomas that recovered spontaneously and 1 patient with complex regional pain syndrome (CRPS) like symptoms that recovered without intervention after 4 weeks). One year after surgery, 77\% reported an excellent or good outcome whereas $85 \%$ had resumed sports activities. It was concluded from this prospective trial that surgery for lat-CECS is successful in 3 of 4 operated patients.

Patients with exertional lower leg pain who exhibit normal intracompartmental pressures occasionally suffer from a peripheral nerve entrapment. In the last three chapters of this thesis, we describe the clinical characteristics of common peroneal nerve (CPN) and tibial nerve (TN) entrapment. In addition, a small CPN case series and a unique case of a CPN schwannoma are described. Aim of these contributions is to increase awareness and to provide simple diagnostic tools. Patients with nerve entrapments often struggle to find the right words to describe the nature of their symptoms. They often feel pain and/or paraesthesias in the affected peripheral nerve territory that is more severe following exertion but may also be present at night. Skin sensation of lower leg portions is often abnormal. Imaging (ultrasound, $\mathrm{MRI}$ ) are usually normal but rarely suggest the presence of a schwannoma. Electromyography (EMG) including nerve conduction studies (NCS) do not indicate abnormalities in case of entrapments. Surgery such a neurolysis is often beneficial.

In chapter $\mathbf{8}$ we discuss characteristics and management of the two most frequent 
nerve entrapments of the lower leg, entrapment of the common peroneal nerve (CPN) and the tibial nerve (TN). Patients report a continuous awkward feeling and pain and sometimes paraesthesia's in the domain of the CPN (anterolateral side of the leg and dorsum of the foot), or TN (anteromedial side of the leg and sole of the foot, respectively), that increased on exertion. Physical examination using a cotton swab (tactile sense) reveals areas of altered skin sensation reflecting the affected nerve whereas pinching of the skin are painful. Tapping of the nerve distal of the fibular head (CPN) or pressuring the soleal sling (TN) may evoking local and distal symptoms (positive Tinel). Results of imaging (X-ray, ultrasound, MRI), electromyography (EMG) and nerve conduction studies (NCS) were normal. The two examples in this overview underwent a successful neurolysis of the entrapped nerve.

Our case series on common peroneal nerve entrapment (CPNE) in chapter 9 includes 5 female patients with a mean age of 49 years. All five reported pain provoked on exertion which limited their physical activities. Moreover, they all experienced pain in rest and had a disturbed sleep. Two patients developed CPNE following trauma and 3 patients developed the entrapment spontaneously. At physical examination, altered skin sensation (4/5), painful skin pinching (4/5) and a positive Tinel at the fibular head (4/5) were often present. Imaging, EMG and NCS were normal. Diagnostic delay was 35 months (range 6-60). The CPN and its side branches were freed from its surroundings through a $5-8 \mathrm{~cm}$ oblique incision of the skin covering the fibular head. Both the nerve's entrance at the muscle heads of the peroneus longus muscle and the exit from the popliteal fossa were widened. Patients reported outcome of neurolysis as excellent $(n=3)$ and good $(n=2) 14$ months postoperatively.

Symptoms mimicking CPNE can occasionally be caused by a schwannoma of the common peroneal nerve. In chapter 10 we describe an unique case of a 41-year old woman with a radiating pain from the lateral aspect of the right knee towards the dorsal portions of the foot, provoked by touching the lateral aspect of the knee, crouching and sitting. On examination, a 1-2 cm swelling was palpated, and ultrasound and MRI confirmed the diagnosis of a CPN schwannoma. Via a $6 \mathrm{~cm}$ longitudinal incision the perineum was opened, and the schwannoma was removed. The patient was completely pain free after surgery. 


\section{NEDERLANDSE SAMENVATTING (Dutch summary)}

Pijnsyndromen van het anterolaterale onderbeen komen regelmatig voor in actieve populaties en beperken sportactiviteiten. In dit proefschrift bestudeerden we meerdere pijnsyndromen van het anterolaterale onderbeen, in het bijzonder het laterale chronische compartimentsyndroom (chronic exertional compartment syndrome, CECS) en aandoeningen van de nervus peroneus communis (CPN).

Over het algemeen wordt aangenomen dat CECS symptomen veroorzaakt worden door verhoogde drukken in één of meer spiercompartimenten (intracompartmental pressure, ICP). Deze verhoogde drukken zouden ontstaan door inspanning en resulteren in relatieve spierischemie, maar over de specifieke pathofysiologie is nog veel onbekend. CECS kan in elke lichaamsspiercompartiment optreden maar komt het meest voor in één van de drie compartimenten in het onderbeen; het anterieure (ant-CECS), diepe posterieure (dp-CECS) of laterale compartiment (lat-CECS).

Volgens de huidige literatuur komt het laterale compartimentsyndroom het minst vaak voor, maar de prevalentie cijfers zijn tegenstrijdig. ${ }^{7,11,13,17,21}$ De studies die een hoge lat-CECS prevalentie beschrijven zien het anterieure en laterale compartimentsyndroom als één entiteit (anterolaterale CECS), maar meten de ICP alleen in het anterieure compartiment. ${ }^{17,21}$ Tot op heden is er niet alleen onduidelijkheid over de prevalentie, maar over bijna alle aspecten van lat-CECS, van patiënt karakteristieken tot optimale conservatieve en chirurgische behandeling.

De huidige kennis over CECS is grotendeels gebaseerd op studies met geselecteerde cohorten zoals atleten en militairen. 6,12,13,24 In hoofdstuk $\mathbf{2}$ beschrijven we een groot heterogeen cohort van 1411 patiënten uit een algemene populatie die tussen januari 2001 en december 2013 in ons ziekenhuis werden onderzocht voor inspanningsgebonden onderbeenpijn. Op basis van anamnese en verhoogde ICP metingen werd de helft van de patiënten gediagnosticeerd met CECS in één of meer compartimenten. De mediane leeftijd was 25 jaar met een range van 12 tot 81 jaar. De prevalentie nam af met leeftijd. Met behulp van een multivariaat regressie model werden jonge leeftijd, mannelijk geslacht, bilaterale symptomen, een blanco onderbeen voorgeschiedenis, een pijnlijk/gespannen compartiment bij lichamelijk onderzoek en schaatsen geïdentificeerd als positieve voorspellers voor CECS. Rennen bleek een negatieve voorspeller voor CECS. Deze factoren werden gecombineerd in een nomogram welke een matig onderscheidend vermogen heeft (AUC 0.66). Dit voorspellende model kan worden gebruikt om de besluitvorming over de indicatie van een ICP te ondersteunen, maar kan niet gebruikt 
worden als een diagnostisch instrument.

Wanneer een patiënt mogelijk CECS heeft, kan een ICP meting de diagnose bevestigen of verwerpen. ${ }^{14}$ De diagnostische waarde van een herhaalde ICP meting (re-ICP) bij patiënten met recidiverende of aanhoudende CECS-achtige symptomen na een fasciotomie of eerdere normale ICP, is echter niet bekend. In hoofdstuk 3 onderzochten we de rol van een re-ICP in deze twee groepen patiënten. Retrospectief bestudeerden we 1714 ICP drukmeting sessies in 1513 patiënten tussen januari 2001 en december 2013. In deze groep waren 71 re-ICP's in 68 patiënten ( $n=55$ na fasciotomie, $n=16$ eerdere normale ICP). De re-ICP was positief in $26 \%$ van alle geopereerde compartimenten en in $15 \%$ van alle compartimenten waarin de eerdere ICP normaal was. We concludeerden dat een re-ICP overwogen kan worden bij patiënten met recidiverende of aanhoudende symptomen wanneer andere oorzaken van inspanningsgebonden onderbeenklachten zijn uitgesloten. Vals positieve uitslagen zijn echter niet uitgesloten.

Zoals eerder besproken zijn er drie typen CECS in het onderbeen: ant-CECS, dp-CECS en lat-CECS. De bijdrage van elk subtype in de totale CECS-populatie is onbekend en onderwerp van discussie. Over het algemeen wordt aangenomen dat ant-CECS en dp-CECS twee verschillende, op zichzelf staande aandoeningen zijn die geïsoleerd voor kunnen komen. ${ }^{2,26}$ Het laterale compartiment wordt daarentegen vaak gezien als een aandoening die alleen in combinatie met ant-CECS voorkomt. ${ }^{10,18}$ In hoofdstuk 4 bestudeerden we of lat-CECS ook geïsoleerd voor kan komen. Bovendien onderzochten we of bepaalde aanwijzingen in anamnese en lichamelijk onderzoek kunnen helpen bij het onderscheiden van de verschillende subtypes, met name van ant- en lat-CECS. In dit retrospectieve onderzoek werden 73 patiënten geïncludeerd van de in totaal 747 patiënten die een ICP ondergingen bij de verdenking CECS. Patiënten werden geïncludeerd als ze gelijktijdig een ICP meting hadden ondergaan in zowel het anterieure als het laterale compartiment. Van deze heterogene populatie met anterolaterale pijn en een strak gevoel werd 7\% gediagnosticeerd met een geïsoleerde lat-CECS (geïsoleerde ant-CECS, $\mathrm{n}=26$; geïsoleerde lat-CECS, $\mathrm{n}=5$; ant/lat-CECS, $\mathrm{n}=42$ ). Er waren geen groepsverschillen in leeftijd (ant-CECS: mediaan 26 jaar (range 13-68); lat-CECS: mediaan, 20 jaar (range 17-63); ant/lat-CECS: mediaan 28 jaar (range 17-57); $\chi^{2}(2)=0.466 ; P=0.79$ ), geslacht (ant-CECS 50\% man, lat-CECS 40\% man, ant/lat-CECS 62\% man; P=0.49), en bilateraliteit (ant-CECS 54\%, latCECS 80\%, ant/lat-CECS 69\%; P=0.40). Alle patiënten rapporteerden pijn en op één patiënt na $(72 / 73,99 \%)$ hadden allen een bepaalde mate van een strak gevoel tijdens inspanning. Een opvallende bevinding was dat de helft aangaf ook 's nachts klachten te hebben. Een deel van de patiënten vermeldde ook sensibiliteitsstoornissen aan onderbeen en/of voet. De locatie 
van deze stoornissen kwam in twee derde echter niet overeen met het innervatiegebied van de nervus peroneus profundus of superficialis, wat erop wijst dat deze informatie niet bruikbaar is voor het stellen van de diagnose. Omdat op basis van anamnese en lichamelijk onderzoek geen onderscheid gemaakt kan worden tussen ant-CECS en lat-CECS terwijl beide compartimentsyndromen geïsoleerd voor kunnen komen, is het gerechtvaardigd om bij patiënten met anterolaterale klachten een ICP van beide compartimenten uit te voeren.

Het anterieure en diepe posterieure compartimentsyndroom zijn beide uitgebreid beschreven in de huidige literatuur. 1, 3, 16, 18, 19, 22, 23, 25 Literatuur over lat-CECS daarentegen is bijzonder schaars. 3, 5, 7, 9, 11, 13-15, 21 In hoofdstuk 5 beschrijven we de demografie en basiskenmerken van een retrospectieve patiëntengroep met geïsoleerde lat-CECS. Tussen januari 2001 en december 2012 ondergingen 1384 patiënten een ICP van wie 678 gediagnosticeerd werden met CECS op basis van de Pedowitz criteria. ${ }^{14}$ Twaalf procent van alle patiënten met een positieve drukmeting werden gediagnosticeerd met lat-CECS, deels geïsoleerd en deels gecombineerd met andere compartimentsyndromen (lat-CECS: $n=28,4 \%$; ant/lat-CECS: $n=33,5 \%$; dp/lat-CECS: n=7, 1\%; ant/dp/lat-CECS: $n=10,1 \%)$. Zesentwintig van de 28 patiënten met geïsoleerde latCECS werden verder bestudeerd. Een kleine meerderheid was vrouw en de mediane leeftijd op moment van diagnose was 27 jaar (range 16-78). Vertraging vanaf het moment van ontstaan van klachten tot aan diagnose was mediaan 24 maanden (range 2 maanden - 10 jaar). Meest genoemde symptomen waren pijn (24/26, 92\%) en een strak gevoel (11/26, 42\%). Soms vermeldden patiënten ook kramp (19\%), een doof gevoel van de huid (15\%) en/of spierzwakte (12\%). Twee derde van de patiënten had klachten aan beide benen (16/24, 67\%, onbekend $\mathrm{n}=2)$. Deze symptomen waren bij $87 \%(13 / 26, \mathrm{n}=11$ onbekend) in een bepaalde mate van invloed op de sportactiviteiten (27\% volledig gestopt met sporten, $47 \%$ ging sporten op een lager niveau, $13 \%$ bleef op hetzelfde niveau sporten met klachten). Deze studie concludeerde dat een klein deel van de CECS patiënten een geïsoleerd compartimentsyndroom heeft van het laterale compartiment. Op basis van de symptomen kan lat-CECS niet onderscheiden worden van andere soorten CECS omdat de symptomen erg op elkaar lijken.

Wanneer een patiënt gediagnosticeerd wordt met CECS wordt hij geïnformeerd over de verschillende conservatieve en chirurgische behandelopties. Vaak ondergaan patiënten eerst conservatieve behandelingen zoals aanpassing van looppatroon, fysiotherapie, koelen of dry needling. Wanneer hiermee niet het gewenste resultaat bereikt wordt, is fasciotomie de behandeling van eerste keus. ${ }^{4,8,20,27}$ Momenteel is weinig bekend over de resultaten van fasciotomie bij patiënten met lat-CECS. In hoofdstuk 6 beschrijven we de resultaten van 
fasciotomie in een retrospectieve groep lat-CECS patiënten. Tussen januari 2001 en december 2012 was er bij 247 patiënten de verdenking op een lateraal compartimentsyndroom en werd een ICP uitgevoerd. Bij 78 van deze patiënten werd lat-CECS gediagnosticeerd. Alle patiënten werden verzocht een vragenlijst in te vullen waarin ze de ernst en frequentie van hun klachten voor en na de operatie aan konden geven. Ook konden ze aangeven wat ze van het operatieresultaat vonden. Succes werd gedefinieerd als een uitstekend of goed operatie resultaat, daarentegen werd een redelijk, matig of slecht resultaat beschouwd als onsuccesvol. In totaal waren 30 vragenlijsten van 67 geïncludeerde patiënten geschikt voor analyse. De meest frequent gerapporteerde symptomen waren bilaterale (80\%) inspanningsgebonden pijn (97\%) en een strak gevoel (93\%). Inspanningsgebonden spierzwakte (73\%), paresthesieën (70\%) en/of kramp (70\%) werden ook frequent vermeld. Vier jaar na fasciotomie waren zowel de ernst als de frequentie van deze klachten significant afgenomen, met een gemiddelde daling van de pijnscore van $>50 \%$. Slechts $33 \%$ van de patiënten gaf aan de operatie uitkomst op de lange termijn succesvol te vinden. Drieënzeventig procent kon na de operatie de sportactiviteiten hervatten, maar vaak op een lager niveau dan voor de start van de symptomen. Uit dit retrospectieve onderzoek concludeerden we dat het operatieresultaat voor lat-CECS op de lange termijn over het algemeen bevorderlijk was, maar dat slechts een derde van de patiënten het resultaat als succesvol bestempelde.

Om de chirurgische resultaten beter te kunnen bestuderen hebben we een prospectieve studie opgezet die we beschrijven in hoofdstuk 7. In ons ziekenhuis waren tussen januari 2013 en april 2019881 patiënten met inspanningsgebonden onderbeen pijn (ELP), waarvan 88 patiënten gediagnosticeerd werden met lat-CECS (man, 57\%; gemiddelde leeftijd 27 jaar, range 15-72). Ernst en frequentie tijdens rust en inspanning van de kardinale CECS symptomen (pijn, strak gevoel, kramp, spierzwakte en paresthesieën) werden gescoord op een 5-punts verbal rating scale (VRS). Dit werd op 3 punten in de tijd gedaan: voor fasciotomie en 3 en 12 maanden na fasciotomie. De meerderheid van de lat-CECS patiënten had ook CECS in een ander compartiment: $61 \%$ ant-CECS, 6\% dp-CECS. Slechts $11 \%$ van de patiënten had een geïsoleerde lat-CECS. De meest voorkomende symptomen (47 patiënten, 78 benen) waren ernstige pijn bij inspanning (>90\%) en een matig strak gevoel in rust (83\%). In 10\% van de patiënten was er sprake van een complicatie ( 2 wondinfecties waarvoor antibiotische behandeling nodig was, 2 spontaan herstelde hematomen en 1 patiënt met een na 4 weken spontaan hersteld complex regionaal pijn syndroom). Een jaar na de operatie beoordeelde $77 \%$ van de patiënten het resultaat als uitstekend of goed en $85 \%$ had zijn of haar sportactiviteiten 
hervat. Concluderend was een fasciotomie succesvol in 3 van de 4 geopereerde patiënten.

Patiënten met inspanningsgebonden onderbeenspijn die geen verhoogde compartimentdrukken hebben, blijken soms te lijden aan een entrapment van een perifere zenuw. In het laatste deel van dit proefschrift worden de klinische karakteristieken van nervus peroneus communis (CPN) entrapment en nervus tibialis (TN) entrapment beschreven. Bovendien beschrijven we een kleine case series van CPN entrapment en een casus van een patiënt met een CPN schwannoom. Doel van deze bijdrage is het vergroten van de bewustwording en het aanreiken van simpele diagnostische instrumenten. Patiënten met een zenuwentrapment hebben vaak moeite om hun klachten goed te beschrijven. Ze hebben vaak last van pijn en/of paresthesieën in het verzorgingsgebied van de aangedane zenuw. Deze klachten zijn meestal erger na inspanning maar kunnen ook's nachts aanwezig zijn. Vaak is de sensibiliteit van delen van het onderbeen gestoord. Beeldvorming (echo, MRI) zijn meestal niet afwijkend maar kunnen bijvoorbeeld de aanwezigheid van een schannoom bevestigen. Ook elektromyografie (EMG) en zenuwgeleidingsonderzoek (nerve conduction studies, NCS) tonen over het algemeen geen afwijkingen bij een entrapment. De resultaten van operatieve neurolyse zijn meestal succesvol.

In hoofdstuk 8 bespreken we de kenmerken en behandeling van entrapment van de nervus peroneus communis en nervus tibialis, de twee meest voorkomende zenuw entrapments in het onderbeen. Patiënten hebben vaak last van een continu vervelend en pijnlijk gevoel en hebben soms ook last van paresthesieën in het verzorgingsgebied van respectievelijk de CPN (anterolaterale zijde van het onderbeen en dorsale zijde van de voet), danwel de TN (anteromediale zijde van het onderbeen en voetzool). Deze klachten zijn normal gesproken erger bij inspanning. Bij lichamelijk onderzoek kan een verstoorde tastzin gevonden worden door met een wattenstaafje over de huid te strijken of door in de huid te knijpen. Symptomen kunnen opgewekt worden door net distaal van het fibulakopje op de zenuw te kloppen (CPN) of door druk uit te oefenen ter plaatse van de "soleal sling", de ruimte tussen de twee aanhechtingspunten van de soleus spier waar de TN onderdoor loopt (positieve Tinel). De resultaten van aanvullende beeldvorming (röntgenfoto, echo, MRI), elektromyografie (EMG) en zenuwgeleidingsonderzoeken (nerve conduction studies, NCS) laten normal gesproken geen afwijkingen zien. De twee voorbeeld patiënten in dit overzicht ondergingen een succesvolle neurolyse van de zenuw.

In de case series in hoofdstuk 9 beschrijven we 5 vrouwelijke patiënten met een gemiddelde leeftijd van 49 jaar met een nervus peroneus communis entrapment (CPNE). Ze 
rapporteerden alle 5 inspanningsgebonden pijn waardoor hun sportactiviteiten gehinderd werden. Bovendien hadden ze ook alle 5 last van pijn in rust en een gestoorde slaap. Twee van de patiënten ontwikkelden CPNE na een trauma, de andere 3 patiënten ontwikkelden de entrapment spontaan. Bij lichamelijk onderzoek waren de meest voorkomende bevindingen een gestoorde sensibiliteit van de huid (4/5), pijn bij knijpen in de huid (4/5) en een positieve Tinel ter hoogte van het fibulakopje (4/5). Bevindingen bij beeldvorming, EMG en NCS waren normaal. De vertraging tot het stellen van de diagnose was 35 maanden (range 6-60). Alle patiënten ondergingen een operatieve behandeling: via een schuine incisie van $5-8 \mathrm{~cm}$ boven het fibulakopje werd de CPN inclusief zijtakken losgemaakt van de omliggende weefsels. Zowel bij de aanhechting van de peroneus longus spier waar de CPN het onderbeen binnentreedt als waar hij de knieholte weer verlaat werden de openingen verwijd. Veertien maanden na de operatie beoordeelden de patiënten de uitkomst van hun operatie als uitstekend $(n=3)$ en goed $(n=2)$.

Symptomen die sterk overeenkomen met CPNE kunnen veroorzaakt worden door een schwannoom van de CPN. In hoofdstuk 10 beschrijven we de casus van een 41-jarige vrouw met pijn die uitstraalt vanuit de laterale zijde van de rechter knie naar de dorsale zijde van de voet. Klachten werden opgewekt door het aanraken van de laterale zijde van de knie, zitten en hurken. Bij lichamelijk onderzoek van het onderbeen was bij palpatie een $1-2 \mathrm{~cm}$ vast-elastische zwelling palpabel aan de laterale zijde van de knie, wat bij echo en MRI bleek te berusten op een schwannoom van de CPN. Via aan longitudinale incisie van $6 \mathrm{~cm}$ werd het perineum geopend en het schwannoom verwijderd. Postoperatief was de patiënte volledig pijnvrij. 